\title{
Antimicrobial Activity of Panchavalkal Powder and Ointment
}

\author{
Dr. Dhammananda Khadkutkar \\ M.D. (RSBK) Scholar, Dept. of Rasashastra and Bhashajya Kalpana \\ Prof. Veena G. Kanthi \\ Principal, Head, Dept. of Rasashastra and Bhashajya Kalpana, Late Kedari Redekar Ayurvedic \\ College and Post Graduate Research Centre, India

\section{Dr. Dudhamal Tukaram} \\ Assistant Professor, Dept. of Shalyatantra, Institute for Post Graduate Teaching and \\ Research in Ayurveda (I.P.G.T. \& R.A.), Gujarat Ayurved University, India
}

\begin{abstract}
Panchavalkala is one of the ideal combinations for a vast range of therapeutics focused in Ayurveda like Vranaropana, Shothahara, Graahi, Visarpahara, etc. Researchers in recent and past evaluated anthelmintic, antimicrobial, wound healing etc. activities of these plants in combination and individual too. Panchavalkal is widely used in different form like Kwath, powder, ointment and Malahara etc. The advantages of different innovative Kalpanas as compare to traditional one have increased shelf life, ready to use, better acceptability and ease of application. The study planned with objective to evaluate in-vitro antibacterial activity of Panchavalkal powder and Panchavalkal ointment. The antimicrobial activity of Panchavalkal powder (traditional) and ointment (conventional) was assessed by adopting agar diffusion method in which different concentrations are incorporated into an agar medium. Replicator device was used to inoculate multiple specimens on to a series of plates with respective standard drugs. Here responses of organism to the trial drugs were measured and compared with respective standard drugs i.e Chloramphenicol, Ciprofloxacin. Micro organisms studied were Pseudomonas aeruginosa (gram-ve), Staphylococcus aureus (gram +ve) and Escherichia coli (gram-ve). Antimicrobial activity of both the samples against three strains of bacteria was in between 10 to 13 that is less as compared to standard. Ointment is sensitive against Staphylococcus aureus and Escherichia coli. The drug is more sensitive for gram positive bacteria i.e. S aurues than that of gram negative bacteria E. coli. Based on this it can be said that the drug Panchavalkala ointment has significant antimicrobial activity against both the strains at concentrations of $0.5 \mathrm{~g}$ and $1.0 \mathrm{~g}$. Panchavalkal powder had found to exhibit antimicrobial action against $S$. aureus. It can be stated that antimicrobial action might increased significantly in Panchavalkal ointment. The increased additional activity might be due to concentrated Panchavalkal in ointment form that clearly proved the role of Samskara. This efficacy may also be due to the other ingredients such as sesame oil and bee wax that are the essential components in preparation of ointment. The study concluded that Panchavalkal ointment is better than Panchavalkal powder as antibacterial agent in cases of Staphylococcus aureus and E. coli infections and need to be evaluated clinically.
\end{abstract}

Keywords: Antimicrobial Activity, Panchavalkal, S. aureus, P. Aeruginosa, E. coli.

\section{INTRODUCTION}

In Ayurveda various formulations such as solid dosage forms (pills, powders), liquid dosage forms (Asavas, Aristhas), and semisolid dosage forms (Ghritas, Avlehas, and Paka) uses for therapeutic purpose. Among all these formulations Choorna (power) Kalpana is one of the most important Kalpana as this form makes the traditional drug more stable for long-term storage and preserve, which can be used for internal and external purpose. Malahara is a unique Kalpana which is one among Bahirparimarjana Chikitsa (external applications). There are no references about this dosage form available in ancient literatures of Ayurveda. Later it gained more importance and was included in the pharmaceutical dosage forms. Siktha Taila, a compound of oil and bee wax is used as a base in most of the Malahara. In Ayurved classic Panchavalkala i.e. the bark of five trees viz. Vața (Ficus bengalensis Linn), Udumbara (Ficus glomerata Roxb.), Ashwattha (Ficus religiosa Linn.), Parisha (Thespesia populenoides L.) and Plakșha (Ficus lacor Buch Ham.) in mentioned in the treatment of Vranashotha (inflammations and abscess) and Vrana (wounds). All the ingredients present in the Panchavalkala has Kashya rasa (Astringent properties) which helps in the Shodhan (cleaning) of 


\section{Dr. Dhammananda Khadkutkar et al.}

Vrana. Individual drugs also have Shothahara (anti-inflammatory), Vedanasthapan (pain reliever), Vranaropak (wound healing), Stambhana (striping action), Raktashodhak (hemostatic), etc properties.In the last few decades, there has been exponential growth in the field of herbal remedies. Pharmacopoeial preparations like Avleha or Paka, Swarasa, Kalka, Hima, Phanta, Kwatha and Choorna form are the backbone of Ayurvedic formulations. Today the Government of India (GOI) has formed stringent to regulate issues related to quality, safety, efficacy, and practice of herbal medicine with a unique holistic approach. Most of the times Chikitsa become unsuccessful due to inefficacy of medicaments which is mostly due to usage of impotent medicament with or without knowledge. As population is increasing, there is also an increasing demand for the medicaments. But at the same time, scarcity of drugs and also medicaments is arising. So it has become necessary to preserve the medicaments. Hence, there is an utmost need to develop new formulation with reference of classics and using different preserving techniques with a hypothesis that the final products are of higher potency, longer shelf life and good acceptance to meet the trend of fast moving people of the present era.

Panchavalkala is one of the ideal combinations for a vast range of therapeutics focused in Ayurveda like Vranaropana, Shothahara, Graahi, Visarpahara, etc. ${ }^{[2]}$ Researchers in recent and past evaluated anthelmintic, antimicrobial, wound healing etc. activities of these plants in combination and individual too. ${ }^{[3]}$ Keeping this in consideration, in present study first time an attempt has been made to convert the new formulation i.e. Panchavalkala Malahara (ointment) and other one is Panchavalkala Choorna.

\section{Materials AND Methods}

\subsection{Collection of Plant Material}

Stem bark of selected plants viz., Panchavalkal is the formulation with barks of five trees viz. Vata (Ficus bengalensis Linn), Udumbara (Ficus glomerata Roxb.), Ashwatha (Ficus religiosa Linn.), Parish (Thespesia populenea Soland ex corea.) and Plaksha (Ficus lacor Buch-Ham.) free from disease were collected from Gadhinglaj, Maharashtra (Table 1). The plants parts were dried in sunlight till it became moister free for 7 days.

\subsection{Preparation of Panchavalkal Powder}

Panchavalkal powder was prepared by adopting classical method of choorna kalpana. ${ }^{[4]}$ Small pieces of Panchavalkal were dried completely and grinding of enough size (sieve number 10). The prepared Panchavalkala Choorna was kept in air tight container for antimicrobial activity.

\subsection{Preparation of Panchavalkal ointment}

$>$ The ointment was prepared by following there stages:

$>$ Preparation of Panchavalkala kwatha

$>$ Preparation of Panchavalkala taila

$>$ Preparation of Panchavalkala ointment

Panchavalkal kwatha was prepared by following specified classical guidelines. ${ }^{[5]}$ Prepared Panchavalkal coarse powder was soaked in 16 times of water for overnight. Next day it was subjected to heat with continuous stirring and the quantity was reduced to $1 / 4$ th of the initial volume. The liquid was filtered through four folded clean cotton cloth and the filtrate was collected as Panchavalkala Kwatha.

Panchavalkala taila was prepared by guideline of sneha Kalpana given by AFI. ${ }^{[6]}$ Panchavalkal kalka (one part) tila taila (4 parts) Kwatha (16 part) was used as Drava Dravya while preparing Panchavalkala Taila. Cotineuos heated and when Siddhi lakshana of Sneha like free from water contents, no cracking sound on fire, froth appearance, desired colour, odour and taste of drug were observed. Then the taila was collected for further use.Panchavalkala ointment was prepared by classical guideline of Rasatarangani. ${ }^{[7]}$ Prepared Panchavalkala tail is added with $1 / 6^{\text {th }}$ part of Siktha (Bee wax) and dissolved properly. Final product Panchavalkal ointment was collected and packed in air tight container for its antimicrobial activity 
Table1. Composition of Panchavalkala: ${ }^{[8]}$

\begin{tabular}{|l|l|l|l|}
\hline Drugs & Latin Names & Part used & Proportion \\
\hline Vata & Ficus bengalensis Linn. & Bark & 1 Part \\
\hline Udumbara & Ficus glomerata Roxb. & Bark & 1 Part \\
\hline Ashwattha & Ficus religiosa Linn. & Bark & 1 Part \\
\hline Parisha & Thespesia populnea Soland. ex Correa. & Bark & 1 Part \\
\hline Plaksha & Ficus lecor Buch. Ham. & Bark & 1 Part \\
\hline
\end{tabular}

\section{Antimicrobial ACTIVIty}

Micro organisms are broadly classified as bacteria, fungi, viruses, actinomytes, etc. These are causative factors in the manifestation of various infectious diseases. Detailed study of these factors, the ways in which they produce diseases in human body and information regarding diagnosis and treatment is essential.

In-vitro tests are used as screening procedure for new agents and for testing the susceptibility of individual isolates from infections to determine which of the available drug might useful therapeutically. In general any compound or drugs that inhibit the growth or cause the death of micro organisms are known as antimicrobial agents. Any drug that inhibits the growth of bacteria or fungi is said to possess bacteriostatic and fungistatic activity respectively. In the current study it is planned to check comparative antimicrobial activity of the Panchavalkal in powder and ointment form.

\section{Materials}

$>$ Panchavalkala powder

$>$ Panchavalkala ointment

\subsection{Place of Study}

The antimicrobial study has been performed on two samples one Panchavalkala powder and Panchavalkala ointment at VASU Research Centre, Vadodara. ${ }^{[9]}$

\section{Sensitivity Testing Method}

\subsection{Microbial Load}

The prepared drugs Panchavalkala powder and Panchavalkala ointment were assessed for their microbial load and any adulteration before going for activity. Those both were found pure and no any microbes isolated.

\subsection{Agar Diffusion Method (Cup Plate Method): ${ }^{[10]}$}

In agar diffusion method different concentrations are incorporated into an agar medium. Replicator device was used to inoculate multiple specimens on to a series of plates with respective standard drugs. Here responses of organism to the trial drugs were measured and compared with respective standard drugs i.e Chloramphenicol, Ciprofloxacin.

\section{Micro Organism}

Following three bacteria were used

$>$ Pseudomonas aeruginosa (gram -ve)

Staphylococcus aureus (gram $+\mathrm{ve})$

Escherichia coli (gram -ve)

\subsection{Standard Inoculum}

Standardization of inoculums is essential to provide reproducible minimum inhibitory concentrations (MICs). It is determined by comparing the turbidity of the liquid medium to a standard that represents a known number of bacteria in suspension. Here inoculums prepared by comparing with Mc Farland standards. ${ }^{[11]}$

\subsection{Material Requirements}

Nutrient Agar (For bacterial cultivation) 
$>12-15$ hours (Overnight) young culture of micro organisms.

Standard solution antibiotics.

Different concentrations of trial drugs.

Sterile petri dishes and sterile cork borer.

Incubator and laminar air flow cabinet ( LAF)

\subsection{Sample Preparation}

For the preparation of test samples of ointment olegenous solvent was used for dissolution. $0.5 \mathrm{gm}$ and $1 \mathrm{gm}$ samples of ointment were dissolved in $5 \mathrm{ml}$ Di methyl sulphoxide (DMSO) and filtered. The samples in the form of solution were then used for determination of antimicrobial activity.

$0.5 \mathrm{gm}$ and $1 \mathrm{gm}$ Choorna of Panchavalkala was taken and were added with $5 \mathrm{ml}$ of Distilled water. Mixtures were stirred well and kept aside undisturbed to sediment. Supernant layers of the mixture was then decanted and filtered. Standard Chloramphenicol and Ciprofloxacin as per IP standard were taken as standard.

\subsection{Culture Conditions}

24 hours old cultures of all these organisms were inoculated in sterile broths and incubated till 0.5 Mac Farland standard turbidity with Barium sulphate suspension obtained and then used for assay.

\subsection{Antimicrobial Assay}

Sterile soyabean casein digest agar $(25 \mathrm{ml}$ per plate) was used in antibacterial activity. $20 \mathrm{ml}$ sterile medium was poured aseptically in sterile plates and allowed to solidify. Then $0.5 \mathrm{ml}$ of culture was inoculated in $5 \mathrm{ml}$ sterile, melted, cooled medium and poured them on solidified agar plates aseptically. After solidification of medium, wells were made with the help of cup borer and $0.3 \mathrm{ml}$ of sample was inoculated.

Two standard drug solutions were added into the well and other standard antibiotic discs were directly placed on agar surface and pressed with the help of sterile forceps aseptically. For diffusion purpose, plates were placed in refrigerator for 20-25 minutes. Then plates were incubated at $37^{0} \mathrm{C}$ for 24 hours. After incubation, zone of inhibition was measured with Himedia antibiotic zone scale- c. $0.3 \mathrm{ml}$ of different extracts as well as Chloramphenicol (30mcg/disk) and Ciprofloxacin (5mcg/disk) standard antibiotic discs were used for the assay.

\section{RESUlts AND DISCUSSION}

Zone of inhibition (ZOI) for $0.5 \mathrm{gm}$ and 1.0 gram is similar that are $13 \mathrm{~mm}$ for Staphylococcus aureus. No Zone of inhibition (ZOI) for Pseudomonas aeruginosa and Escherichia coli was found. Antibacterial activity of Panchavalkal ointment at two different concentrations is observed that zone of inhibition in between both concentrations i.e. $0.5 \mathrm{gm}$ and $1.0 \mathrm{gm}$ was insignificant with $12 \mathrm{~mm}$ and $13 \mathrm{~mm}$ respectively againest Staphylococcus aureus. Zone of inhibition against Escherichia coli was found to be $11 \mathrm{~mm}$ and $10 \mathrm{~mm}$ with $0.5 \mathrm{gm}$ and $1.0 \mathrm{gm}$ respectively. No zone of inhibition (ZOI) was observed against Pseudomonas aeruginosa. (Table -2)

Table 2. Antimicrobial activity of Panchavalkala formulations

(Powder: $0.5 \mathrm{~g}$ and $1.0 \mathrm{~g}$ of the sample dissolved in $5 \mathrm{ml} \mathrm{D} / \mathrm{W}$ ), (Ointment: $0.5 \mathrm{~g}$ and $1.0 \mathrm{~g}$ of the sample dissolved in $5 \mathrm{ml}$ DMSO

\begin{tabular}{|l|l|l|l|}
\hline Test drugs & Microbes and ZOI & \multicolumn{2}{l|}{} \\
\hline Panchavalkala Forms & P.aeruginosa & S.aurues & E.coli \\
\hline $0.5 \mathrm{~g}$ Choorna & No ZOI & $13 \mathrm{~mm}$ & No ZOI \\
\hline $1.0 \mathrm{~g}$ Choorna & No ZOI & $13 \mathrm{~mm}$ & No ZOI \\
\hline $0.5 \mathrm{~g}$ ointment & No ZOI & $12 \mathrm{~mm}$ & $11 \mathrm{~mm}$ \\
\hline $1.0 \mathrm{~g}$ ointment & No ZOI & $13 \mathrm{~mm}$ & $10 \mathrm{~mm}$ \\
\hline Standard Antibiotics & P.aeruginosa & S.aurues & E.coli \\
\hline Chloramphenicol 30mcg/disk & No ZOI & $31 \mathrm{~mm}$ & $27 \mathrm{~mm}$ \\
\hline Ciprofloxacin 5mcg/disk & No ZOI & $36 \mathrm{~mm}$ & $32 \mathrm{~mm}$ \\
\hline
\end{tabular}

D/W: Distilled Water; DMSO: Di Methyl Sulphoxide; P.aeruginosa: Pseudomonas aeruginosa;

S.aurues: Staphylococcus aureus; E.coli: Escherichia coli; ZOI: Zone of Inhibition. 


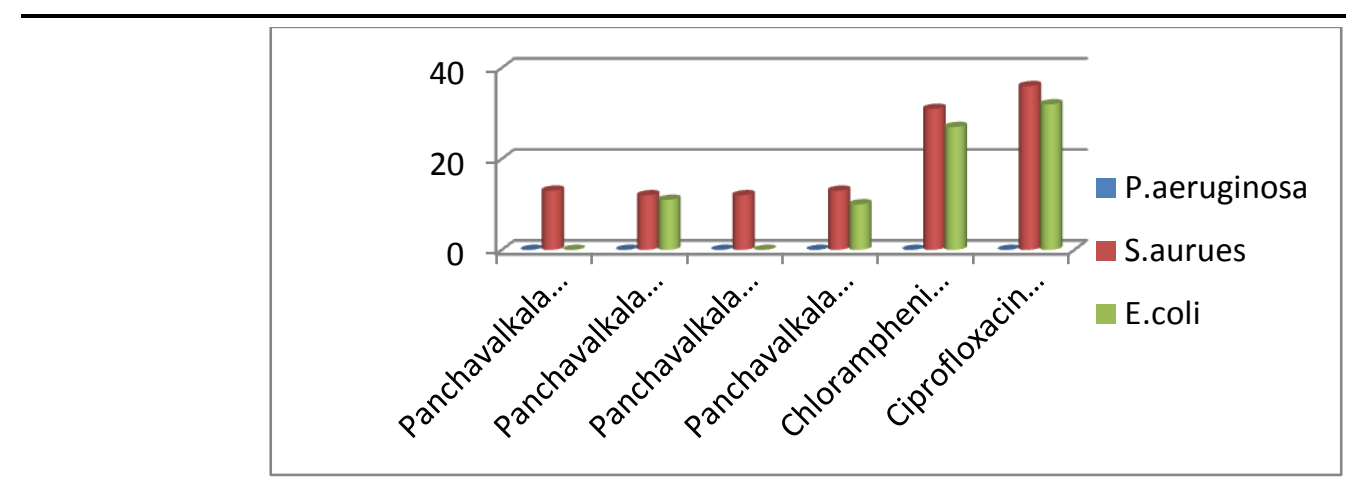

Graph1. Antimicrobial activity of Panchavalkala Powder and Ointment

Panchavalkala ointment showed ZOI for Staphylococcus aureus $12 \mathrm{~mm} \& 13 \mathrm{~mm}$ at $0.5 \mathrm{~g}$ and $1 \mathrm{gm}$ concentration respectively (Figure-1a \& b) and Panchavalkala powder showed ZOI for Staphylococcus aureus $13 \mathrm{~mm} \& 13 \mathrm{~mm}$ at $0.5 \mathrm{~g}$ and $1 \mathrm{gm}$ concentration respectively (Figure-2a \& b). Panchavalkala ointment showed ZOI for Escherichia coli $11 \mathrm{~mm} \& 10 \mathrm{~mm}$ at $05 . \mathrm{g}$ and $1 \mathrm{gm}$ concentration respectively (Figure-3 a \& b) but Panchavalkala powder did not shown ZOI for Escherichia coli (Graph-1). Panchavalkala ointment and powder are having less antimicrobial activity in comparison to standard antibiotics (Chloramphenicol and Ciprofloxacin). But the Panchavalkala ointment is more effective than and Panchavalkala powder.

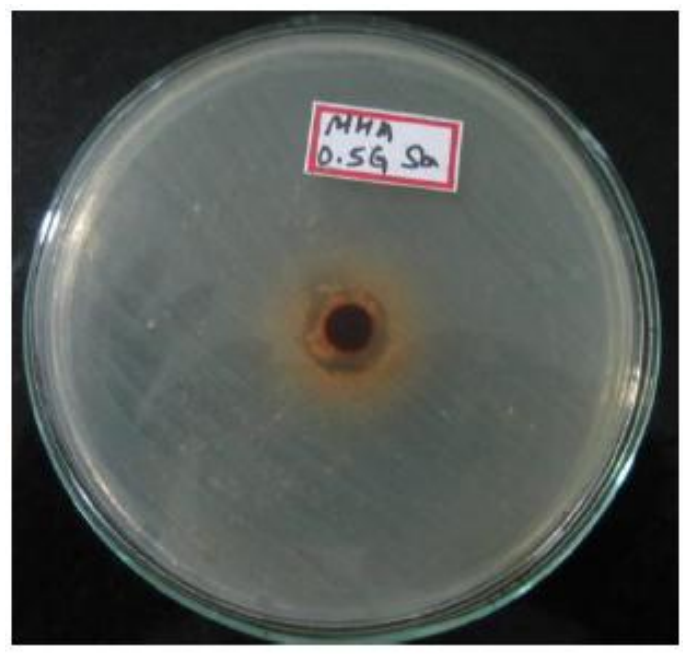

Figure-1 a: 0.5 gm Choorna showing ZOI of $\mathbf{1 3 m m}$ against S.aureus

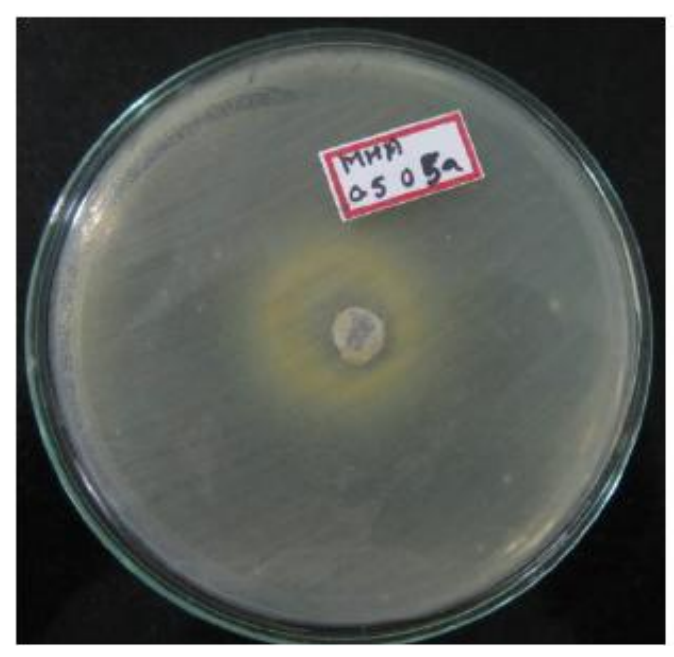

Figure-2 a: 0.5 gm ointment showing ZOI of $\mathbf{1 2 m m}$ against S.aureus

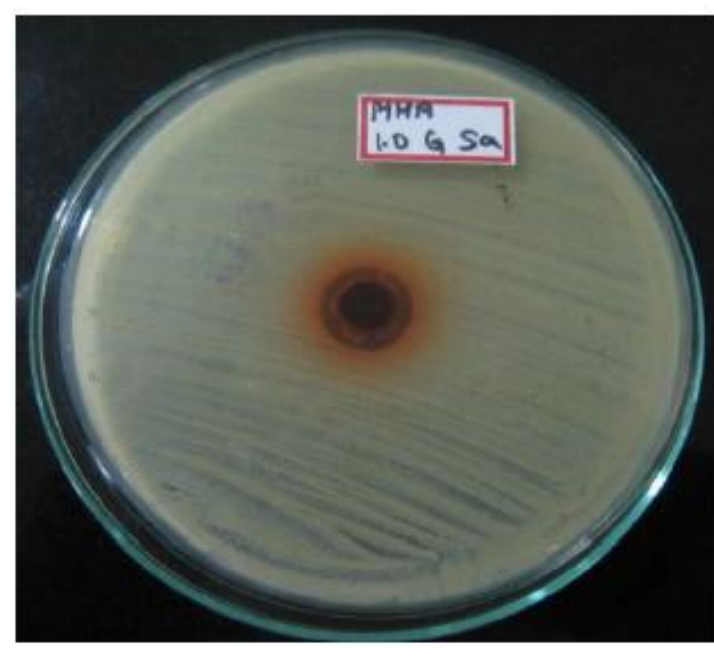

Figure-1 b: 1 gm Choorna showing ZOI of $\mathbf{1 3 m m}$ against S.aureus

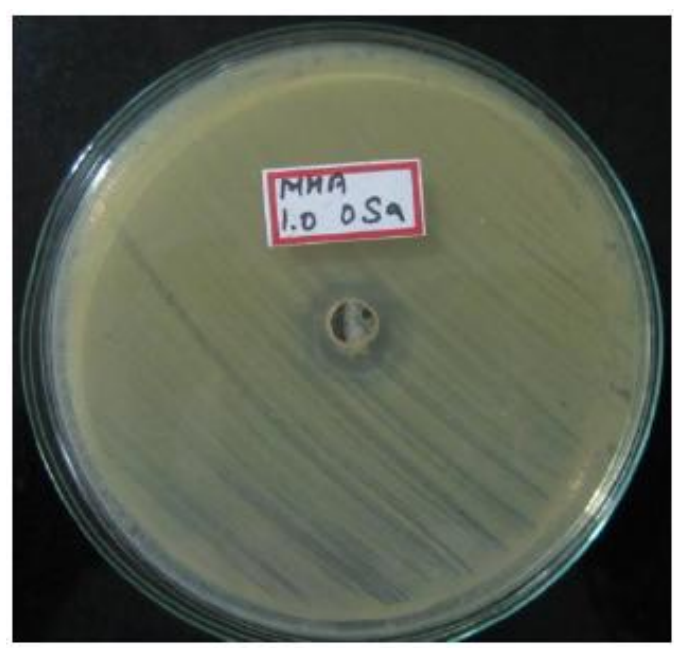

Figure-2 b: 1 gm ointment showing ZOI of $\mathbf{1 3 m m}$ against S.aureus 


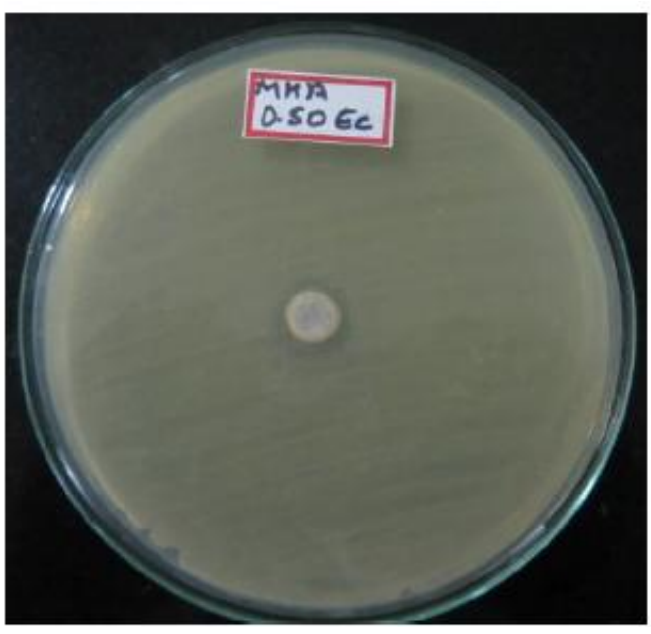

Figure-3 a: 0.5 gm ointment showing ZOI of $\mathbf{1 1 m m}$ against E.coli

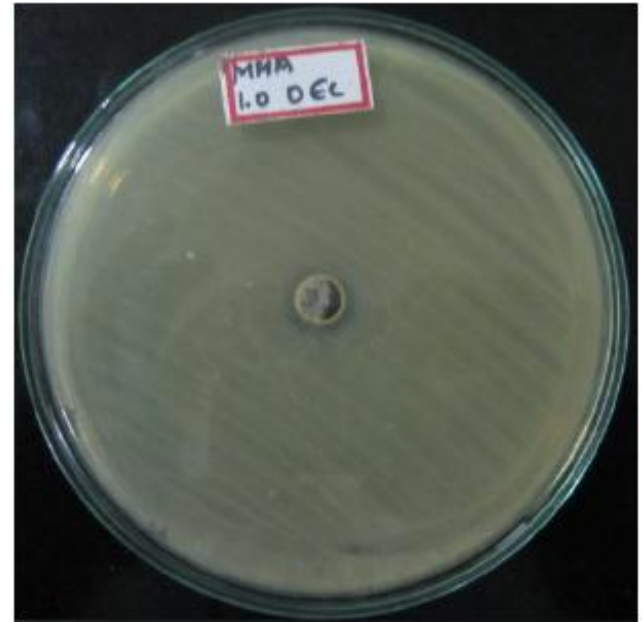

Figure-3 b: 1 gm ointment showing ZOI of $\mathbf{1 0 m m}$ against E.coli

Ointment is sensitive against Staphylococcus aureus and Escherichia coli. The drug is more sensitive for gram positive bacteria i.e. $S$ aurues than that of gram negative bacteria $E$. coli. Based on this it can be said that the drug Panchavalkala ointment has significant antimicrobial activity against both the strains at concentrations of $0.5 \mathrm{~g}$ and $1.0 \mathrm{~g}$. Panchavalkala Choorna had found to exhibit antimicrobial action against $\mathrm{S}$. aureus. It can be stated that antimicrobial action might increased significantly in Panchavalkala ointment.

Antimicrobial activity of both the samples against 3 strains of bacteria was in between 10 to 13 that is less as compared to standard. Antibacterial property of Panchavalkala ointment was found similar as that of Panchavalkala powder against Staphylococcus aureus. Panchavalkala ointment showed additional antibacterial property against E. coli which was not exhibited by Panchavalkala powder. The increased additional activity might be due to concentrated Panchavalkala in ointment form that clearly proved the role of Samskara. Previous clinical research work carried out on panchavalkal ointment and cream in the management of wounds showed encouraging results which support this invitro study. ${ }^{[12-13]}$ This efficacy may also be due to the other ingredients such as sesame oil and bee wax that are the essential components in preparation of ointment. The study supports that ointment is better than the conventional powder form in case of external application as antibacterial agent in cases of Staphylococcus aureus and E. coli infections.

\section{REFERENCES}

[1] A. Shastri, Bhaishjya Ratnavali. $19^{\text {th }}$ ed. Chaukhambha Prakashan, Varanasi.: 2008, Ch.47, Verse-8 and 40, pp. 844, 848.

[2] B. Tripathi, Charaka Samhita, Part-II, reprint ed.Chaukhambha Subharati Prakashan, Varanasi.: 2013, Ch. 25, verse-67, pp. 851.

[3] Khadkutkar DK, Kanthi VG. A Brief Review of Research Studies Conducted on Panchavalkal Indian Journal of Ancient Medicine and Yoga. 8(2) (2015): 87-93.

[4] KRS Murthy, Sharangadhara Samhita, Section-II, $5^{\text {th }}$ ed. Chaukhambha Orientelia,Varanasi.: 2003, Ch.6, Verse-1, pp.84.

[5] KRS Murthy, Sharangadhara Samhita, Section-II, $5^{\text {th }}$ ed. Chaukhambha Orientelia,Varanasi.: 2003, Ch. 2, Verse-1, pp. 56.

[6] Ayurvedic Formulary of India, Part-II, first ed. GOI, MH\&FW, Dept. of ISM\&H, Delhi.: 200 Taila kalpana , pp. 99.

[7] S. Sharma, Rasatarangani, Reprint ed., Motilal Banarasi Dasa, Varanasi: 2006, Ch-4, verse 5961, pp.114-115.

[8] KRS Murthy, Sharangadhara Samhita, Section-II, $5^{\text {th }}$ ed. Chaukhambha Orientelia,Varanasi.: 2003, Ch.2, Verse-149, pp.73.

[9] VASU (A division of Vasu Health care Ltd. ISO 9001 certified company) 067/4, GIDC, Makarpura, Vadodara-390010, Gujarat. 
[10] Ohwada K., Agar Plate Method for Detection and Enumeration of Alkylbenzenesulfonate Degrading Microorganisms. Applied Microbiology, 1975; 29 (1): 40-43.

[11] http://www.pro-lab.com/inserts/McFarland.pdf assessed on dated 17.2.16

[12] Meena RK, Dudhamal T, Gupta SK, Mahanta V. Wound healing potential of Pañcavalkala formulations in a postfistulectomy wound. Ancient Sci Life 2015;35:118-21.

[13] Bhardwaj A. Sahu M., Role of Panchavalkala Kwatha in preoperative skin preparation. PG Thesis Banaras Hindu University, Varanasi-2007 